\title{
APPLIED PRODUCTIVITY MEASUREMENT WITH OBJECTIVE MATRIX (OMAX) METHOD (Case Study: Service Department in PT. Astra International Tbk Auto 2000 - Kenjeran
Branch)
}

\author{
Suparto \\ Industrial Engineering ITATS \\ e-mail: suparto@itats.ac.id
}

\begin{abstract}
PT. Astra International Tbk. Auto 2000 branch Kenjeran is a company department in sales, service and spare parts services. To evaluate the productivity in the service department for this time, it is necessary to measure productivity properly and correctly because productivity measures can be used as material for consideration in carrying out an upcoming productivity planning. This research was conducted in January-December 2013. The productivity method used is the Objective Matrix (OMAX) method. From the results of productivity measurements, it is known that the best productivity occurs in July, which is equal to 768.8 , well above the standard value of 300 . The worst productivity occurred in February, which amounted to equal 174,8. From the achievement of the score it can be seen that the criteria that do not contribute to the productivity index are criteria 1, namely the comparison between unit handling and the use of working hours because it has the smallest score to equal 47. The strategy for increasing productivity is to evaluate the causes of decreasing productivity in the lowest criteria.
\end{abstract}

Key words: Productivity, OMAX, Auto 2000.

\section{INTRODUCTION}

Productivity measurement as a basis for planning is very important at all economic levels. In companies, productivity measurement is used to analyse and encourage production efficiency. Productivity is one indicator of the health rating of a company that needs to be done in assessing the efficiency of conversion of its resources into goods or services, so that the cause of the emergence of productivity problems can be eliminated. PT. Astra International Tbk is one of the companies department in the automotive sector that has received official recognition from the Indonesian government as the sole agent in selling Toyota-branded motorized vehicles to the entire territory of Indonesia. As the largest network dealer in Indonesia, PT. Astra International Tbk, Auto 2000 leads the vehicle sales of Toyota vehicles with various models, Auto 2000 contributes substantially to the $31.1 \%$ market share of Toyota vehicle products in Indonesia. Showroom as one of the facilities and assets that are owned, becomes the main attraction for an automotive dealer.

PT. Astra International Tbk, Auto 2000 Kenjeran is a company engaged in the field of goods and services. With increasing competition and increasingly competitive automotive market, PT. Astra International Tbk. Auto 2000 Kenjeran seeks to improve company productivity in an effort to face increasingly competitive competition. Increased productivity of the company will increase profits, and company profits can be used to developt within the company and to improve arbeiter welfare.

In actual terms, productivity at Auto 2000 Kenjeran experiences an up and down phase, this up and down phase can be seen from the productivity above or below the target. Changes that are below the target must not be too significant or exceeded drastically and productivity must be increased immediately. To increase productivity it is necessary to measure productivity which will provide an evaluation of productivity. To conduct an evaluation, a report is needed that can provide information about productivity, so the company can make strategic plans for the units that allow for increased productivity. Productivity measurement is an important information to assess the efficiency and effectiveness of a program, so that it can be used as a basis in determining the direction of the company's development for the future. By evaluating the results of productivity 
measurement, the factors that cause productivity decline will be known, so that the results of the evaluation can be planned to increase productivity. Based on this background, the purpose of this study is to measure work productivity in the service department of PT. Astra International Tbk. Auto 2000 Kenjeran.

Muhammad Kholil (2010), conduct research with the title of Productivity Measurement Analysis with the Objective Matrix Method in the Production Department of PT. MacroprimaPanganutama. The problems discussed in this study are how to measure company productivity and what plans should be taken so that the company's productivity for the future increases.Using the Objective Matrix (OMAX) method, the overall productivity values for the six months from January-June 2009 are as follows: 325, 227, 352, 321, 322, and 332 . The ratio that is less contributes to the increase in production line productivity and need to be fixed is a ratio of 7 , because it is dominated by poor productivity values. In addition, it is also in other ratios because it is still dominated by moderate productivity values. The step of improving productivity in order to plan productivity improvement in the future is to prioritize the ratio that has the worst value to be improved.

SudiyartodanWaskito (2011) conduct research with the title of Measurement Analysis and Productivity Evaluation by the OMAX method in the Production Section of the Gempolkerep Sugar Factory in Mojokerto. The method used is OMAX productivity analysis (Objective Matrix), which is a productivity measurement technique involving four criteria that influence productivity, such as basic commodity criteria, company office hours criteria, labor criteria, and product quality criteria. Based on the results of productivity measurements at the GempolKerep Sugar Factory, namely in 2005, the company had a productivity index increased by $32 \%$ compared to 2004 , meaning the results of the overall performance of each part, or total company productivity increased.

Avianda, Yuniati, danYuniar (2012) conduct research with the title of Productivity Enhancement Strategy on the Production Floor using the Case Study Objective Matrix (OMAX) method at PT. Agronesia BMC. Based on the results of the calculation of OMAX, the lowest value of the ratio is ratio 5 , which is the total product produced against electricity consumption. Analysis in ratio 5 is done using the fault tree analysis (FTA) method to get recommendations for strategies to increase productivity. Saddad, DeorantoddanDewi (2012) conduct research with the title of Productivity Analysis of Processing Section Using Objective Matrix (OMAX) Method (Study Case in PT Nusantara Plantation XII NgrangkahPawon Regency Kediri). The proposed improvement in productivity improvement at PTPN XII NgrangkahPawon is to produce a product of $18,586.6 \mathrm{~kg}$ required $75,310.37 \mathrm{Kg}$ of raw materials (glondong coffee) with efforts to improve the quality of raw materials; 495 Work Day People (OHK) workforce by seeking to determine the optimal number of workers; $500.92 \mathrm{mStp}$ of wood fuel by trying to smooth the drying process; 92.12 working hours of the generator engine by seeking the correct use and smooth processing; and electricity as much as $1,489.19 \mathrm{KWH}$ by making efficient use of electricity. Before the research was conducted to produce an output of $18,586.6 \mathrm{Kg}$, it was used $81,333 \mathrm{Kg}$ of raw material, $538 \mathrm{OHK}$ of labor, $935 \mathrm{mStp}$ of wood fuel, 141 hours of work on generator engines, and 1,983 KWH of electric energy.

\section{RESEARCH METHODOLOGY}

The method or technique used in conducting data collection is by using questionnaires and interviews. Primary data in this study was obtained by direct interview with Service Manager and General Affairs at Auto 2000 Kenjeran and also conducted research using questionnaires to be filled out by the Branch Manager and Service Head. Secondary data obtained include; organizational structure, data on company production, and data from the internet as well as data from books related to productivity measurement to support primary data.

The processing of primary data and secondary data is obtained, data processing is done using the OMAX method, data that has become several productivity criteria is entered into the OMAX method system.

\section{RESULT AND DISCUSSION}

In Table 1 below, input and output data are presented which will determine the productivity value of the company concerned. Output data in 
the table is unit handling while the input data is; working hours, electrical energy, number of human resources, customer units that are not satisfied and use of water. In full, these data are presented in the following table:

Table 1. Input and Output Data for Calculation of 2013 Productivity Values

\begin{tabular}{lcccccc}
\hline Month & $\begin{array}{c}\text { Handling } \\
\text { Unit } \\
(1)\end{array}$ & $\begin{array}{c}\text { Work hours } \\
\text { (Hours/Month) } \\
(2)\end{array}$ & $\begin{array}{c}\text { Electrical } \\
\text { Energy } \\
(\text { KWH) } \\
(3)\end{array}$ & $\begin{array}{c}\text { Total } \\
\text { Human } \\
\text { Resources } \\
(4)\end{array}$ & $\begin{array}{c}\text { Customer } \\
\text { unit is not } \\
\text { satisfaction } \\
(5)\end{array}$ & $\begin{array}{c}\text { Water } \\
\text { usage } \\
(\text { M3) } \\
(6)\end{array}$ \\
\hline January & 1190 & 167 & 17.937 & 14 & 52 & 312 \\
February & 1140 & 160 & 17.358 & 14 & 49 & 276 \\
March & 1203 & 158 & 16.862 & 14 & 52 & 288 \\
April & 1248 & 174 & 18.513 & 14 & 46 & 321 \\
May & 1259 & 169 & 19.648 & 14 & 56 & 308 \\
June & 1160 & 158 & 19.556 & 14 & 43 & 270 \\
July & 1461 & 181 & 23.902 & 16 & 55 & 316 \\
August & 1222 & 141 & 17.325 & 16 & 44 & 266 \\
September & 1325 & 167 & 22.325 & 16 & 52 & 302 \\
October & 1327 & 174 & 23.916 & 16 & 51 & 321 \\
November & 1313 & 165 & 17.946 & 16 & 51 & 292 \\
December & 1368 & 160 & 24.332 & 16 & 63 & 319 \\
\hline
\end{tabular}

\section{Calculation of OMAX Criteria}

The productivity criteria for unit handling capacity by working hour (ratio 1) is a comparison of the capacity of the car handled for one month with working hours. Ratio 2 is a comparison between the number of handling units and the use of electricity every month. Ratio 3 is a comparison between the number of car handling units and the number of engineer (HR). Ratio 4 is a quality ratio which is a comparison between car unit handling and customers who are not satisfied with the results of improvement. Ratio 5 is a comparison between car unit handling and the use of water resources.From the comparison of unit handling (1) with each input; working hours (2), electrical energy (3), number of HR (4), dissatisfied customers (5), and water use (6) obtained minimum ratios, maximum ratios and average ratios for each of the five ratio criteria.

Table 2. Ratio Level Values for the Five Ratio

\begin{tabular}{lccccc}
\hline Ratio level & Ratio 1 & Ratio 2 & Ratio 3 & Ratio 4 & Ratio 5 \\
\hline Minimum Ratio & 7,13 & 0,055 & 76,38 & 21,71 & 3,81 \\
Average ratio & 7,72 & 0.064 & 84,61 & 24,93 & 4,24 \\
Maximum ratio & 8,67 & 0.073 & 91,31 & 27,77 & 4,62 \\
\hline
\end{tabular}

After the results of the company productivity measurements have been determined, the next step is to analyze the results that have been measured. The benefit of analyzing the results here is to provide a more detailed picture of the conditions regarding the condition of company productivity during the measurement period. Analysis of the achievement of company productivity for each criteria measuring productivity in each period and analyzing the total productivity of the company during the period of measurement carried out.

Explanation:

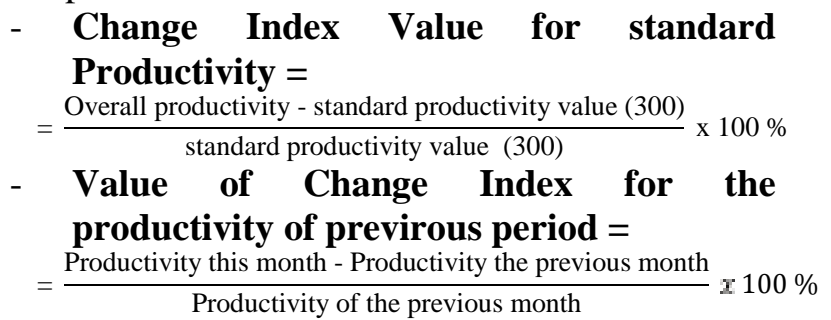




\section{Tibuana}

Journal of applied Industrial Engineering-University of PGRI Adi Buana

Table 3. Table of Changes in Productivity Index Value

\begin{tabular}{lccc}
\hline \multicolumn{1}{c}{ Month } & $\begin{array}{c}\text { Overall } \\
\text { Productivity } \\
(\mathrm{OP})\end{array}$ & $\begin{array}{c}\text { Index value } \\
\text { changes to } \\
\text { standard } \\
\text { productivity }\end{array}$ & $\begin{array}{c}\text { Value of Change } \\
\text { Index for the } \\
\text { productivity of the } \\
\text { previous period }\end{array}$ \\
\hline January & 268,9 & $(-) 10,37 \%$ & - \\
February & 174,8 & $(-) 41,73 \%$ & $(-) 34,99 \%$ \\
March & 399,8 & $(+) 33,27 \%$ & $(+) 128,71 \%$ \\
April & 703,4 & $(+) 134,47 \%$ & $(+) 75,94 \%$ \\
May & 384,8 & $(+) 28,27 \%$ & $(-) 45,29 \%$ \\
June & 528,8 & $(+) 76,27 \%$ & $(+) 37,42 \%$ \\
July & 768,8 & $(+) 156,27 \%$ & $(+) 45,39 \%$ \\
August & 683,7 & $(+) 127,9 \%$ & $(-) 11,07 \%$ \\
September & 404,4 & $(+) 34,8 \%$ & $(-) 40,58 \%$ \\
October & 381,9 & $(+) 27,3 \%$ & $(-) 5,56 \%$ \\
November & 561,2 & $(+) 87,07 \%$ & $(+) 46,95 \%$ \\
December & 268 & $(-) 10,67 \%$ & $(-) 52,25 \%$ \\
\hline
\end{tabular}

From the evaluation table of productivity levels obtained from the OMAX calculation, it can be seen that the best productivity occurs in July, which is equal to 768.8 far above the standard value of 300 . The worst productivity occurred in February, which amounted equal to 174.8 .

From the index of changes to productivity towards standard productivity, it can be seen that in July it was the largest value of $156.27 \%$. while February is the worst value of standard productivity which is equal to $-41.73 \%$.

For the index value of changes to the productivity of the previous period, it can be seen that the largest value occurs in March which is equal to $128.71 \%$ which is the largest increase from February. Meanwhile, the worst decline in productivity occurred in December, which was $-52.25 \%$ from November.

\section{Total Productivity}

Total productivity is the overall productivity of each criterion multiplied by the weight of each of the criteria. Productivity that occurs in each month in 2013 changes and there is an increase and there is a decrease, the upward fluctuations in productivity in each month are caused by many factors. The following is a graph of productivity in 2013:

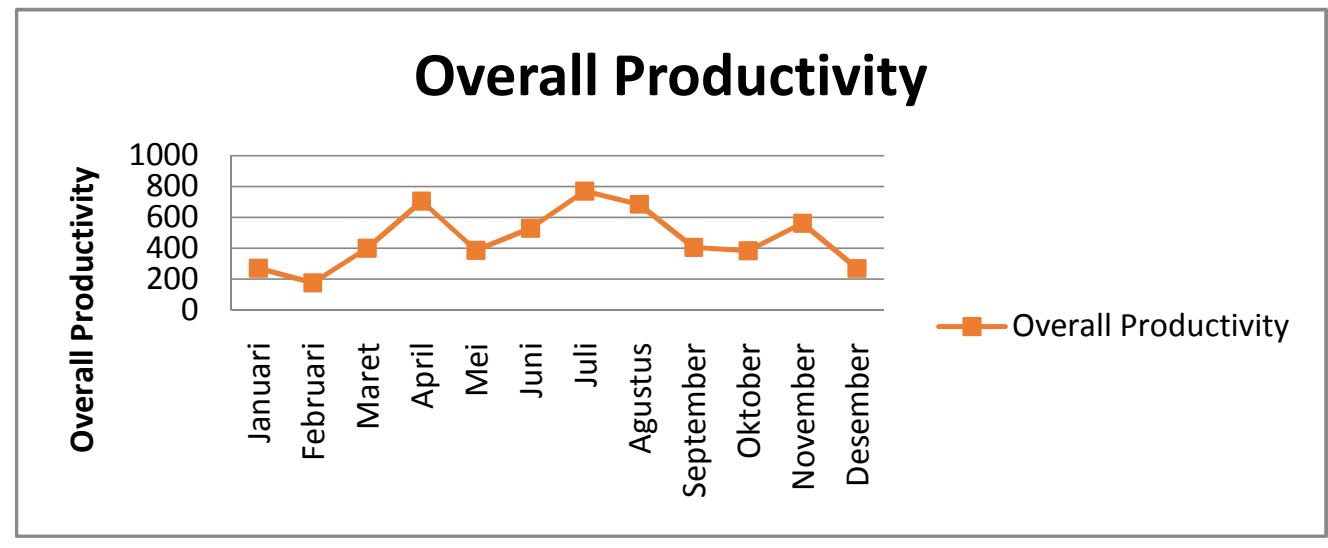

Figure 1. Overall Productivity Graph 


\section{Tibuana}

Journal of applied Industrial Engineering-University of PGRI Adi Buana

p-ISSN 2622-2027

$e$-ISSN 2622-2035

From the graph above it can be seen that the overall productivity fluctuates up and down from January to December 2013. Values that are below standard productivity occur in January, February, and December while values that are above the standard productivity value occur in March, April, May, June, July, August, September, October and November. At the beginning of 2013 the total value of productivity was small, this was due to many factors that caused it. From the graph, it can be seen that the best total productivity occurred in July with a score of 717.3 where in that month was the highest score in 2013. But after August its productivity decreased in September and October to rise again in November with a value of 561,2 .

\section{CONCLUSION}

From productivity analysis in the service department at PT. Astra International Tbk. Auto 2000 Kenjeran using the objective matrix (OMAX) method, it can be concluded that :

1. The best productivity occurred in July which was equal to 528.8 far above the standard value of 300 . The worst productivity occurred in February which was equal to 174.8 .

2. From the index of changes to productivity towards standard productivity, it can be seen that in July it was the largest value of $156.27 \%$. while February is the worst value of standard productivity, which is $-41.73 \%$.

3. For the index value of changes to the productivity of the previous period, it can be seen that the largest value occurred in March which was equal to $128.71 \%$ which was the biggest increase from February. Whereas the worst decrease in productivity occurred in December, which was $-52.25 \%$ from November.

\section{REFERENCE}

[1] Anggraeni Santi Kirana, Katili Putri Bhuana, dan Satriansya Marisa, Pengukuran Kinerja Kualitas Pelayanan Menggunakan Metode Omax Pada
Departemen Logisti Service PT. X, Jurusan Teknik Industri, Universitas Sultan Ageng Tirtayasa ; 2013

[2] Agustina Fitri dan Riana Aris. Analisis Produktivitas dengan Metode Objective Matrix (OMAX), Jurnal Teknik dan Manajemen Industri Vol. 6, No.2 Desember 2011 hal.150-158 Jurusan Teknik Industri, Universitas Trunojoyo Madura ; 2011

[3] Arman, Hakim Nasution. Manajemen Industri, Yogyakarta. Penerbit Andi ; 1990.

[4] Gaspersz Vincent, M.St., CIQA, CPIM, Manajemen Produktivitas Total (strategi peningkatan produktivitas bisnis Global), PT. Gramedia Pustaka Utama Jakarta ; 2000

[5] Henni, Pengukuran Tingkat Produktivitas Lini Produksi PT Kabelindo Murni dengan Menggunakan Pendekatan Metode Objective Matrix (OMAX). Enase vol 5, no 1 , pp. $60-70 ; 2008$

[6] Kholil Muhammad, Analisa Pengukuran Produktivitas Dengan Metode Objective Matrix (OMAX) pada Departemen Produksi, Jurnal Sinergi Vol. 14, No.1 Jurusan Teknik Industri, Universitas Mercu Buana Jakarta ; 2010

[7] Nurdin, R. Zabidi, Y. Pengukuran dan Analisis Produktivitas dengan Menggunakan Metode Objective Matrix. Yogyakarta: STTA ; 2004

[8] Saaty, T. L, Pengambilan Keputusan, PT. Pustaka Binaman Pressindo, Jakarta ; 1993

[9] Sinungan, Drs. M. Produktivitas Apa dan Bagaimana, PT Bumi Askara Jakarta $13220 ; 2004$

[10] Susanti Lusi, Fatrias Dicky dan Kalangi Silviana, Strategi peningkatan produktivitas dilantai Produksi menggunkan Metode Objective Matrix (OMAX), Jurnal Reka Integra ISSN, Vol.01 Jurusan Teknik Industri Universitas Nasional Bandung (Itenas) ; 2014 